\title{
Performance of Rice under Integrated Nutrient Management: A Review
}

\author{
Syed Abul Hassan Hussainy ${ }^{1}$ and S. Arivukodi ${ }^{2}$ \\ ${ }^{1}$ Department of Agronomy, Tamil Nadu Agricultural University, \\ Coimbatore, Tamil Nadu, India \\ ${ }^{2}$ S. Thangapazham Agricultural College, Tenkasi, Tamil Nadu, India \\ *Corresponding author
}

\section{Keywords \\ Integrated nutrient management, \\ Farmyard manure, Green leaf manure, Vermicompost, Poultry manure \\ Article Info \\ Accepted: \\ 12 December 2019 \\ Available Online: \\ 10 April 2020}

\section{A B S T R A C T}

Excessive application of chemical fertilizers to attain higher yield has not only reduced the nutrient use efficiency but has also adversely affected the soil productivity and environmental stability. For this reason, immediate conversion to organic farming would drastically reduce production at initial phases which is of major concern to feed the growing population. This article is written with prime focus to notify on the yield variability under different integrated nutrient management approaches from research conducted worldwide. Organic manures like farmyard manure (FYM), green leaf manure (GLM), vermicompost (VC) and poultry manure (PM) are prioritized due to local availability with integration with inorganic fertilizers on growth and yield of rice. From the study, integrated nutrient management is the best practice over chemical fertilizers and also over complete shift to organic cultivation in terms of improving productivity and also maintaining soil health but over a long run. Selection of organic manures can be made from local availability to decrease the cost of cultivation over inorganic fertilizers as well as other organic sources of fertilizers.

\section{Introduction}

Rice (Oryza sativa L.) is one of the principal food crops in India and it is grown in diverse agro-ecosystems. After the green revolution, due to the introduction of high yielding and fertilizer responsive varieties, rice cultivation has been intensified and has led to increase the use of chemical fertilizers and pesticides. This increased use of chemicals led to several harmful effects on soil, water and atmosphere causing pollution and reduced productivity of the soil (Surekha et al., 2008).

To sustain the soil health and to provide adequate plant nutrition, an alternative to chemical fertilizers need to be supplied in integration as sudden stoppage of chemical and total conversion to organic would lead to drastic yield gaps during the early stages 
(Singh et al., 2009a). The demand for rice is expected to rise @ 1.6 per cent per year due to increase in population, while the area under rice cultivation is expected to reduce to 40 million ha in the next 15 to 20 years (Shobarani et al., 2010). Hence, there is a need to increase the yield and productivity of rice cultivation using reduced inputs and resources to feed the burgeoning population. Moreover, increased cost of chemical fertilizers is reducing the profitability of cultivation. Therefore, alternative use of organic manures like green manuring and crop residues along with inorganic fertilizers not only reduces the demand of inorganic fertilizers, but also increases the efficiency of applied nutrients due to favourable effect on physical, chemical and biological properties of soil(Prasad et al., 1992).

The effectiveness of integrated nutrient management practice can depend on season, soil type, climate, water management, variety and cropping pattern. Thus, this article is written to discuss on the nutrient management strategy involving alternate nutrient management at timing and rates, and integration of organic and other inorganic sources of fertilizers.

\section{Effect of inorganic fertilizer on soil fertility}

Several long-term experiments conducted all over India indicated that a decrease in rice productivity was noticed due to continuous use of chemical fertilizers (Prasad et al., 1995). Basumatary and Talukdar (1998) indicated that continuous application of chemical fertilizer alone decreased the $\mathrm{pH}$, organic carbon, cation exchange capacity and available $\mathrm{N}$ content of soil, whereas an improvement over initial value resulted under integrated treatments receiving both inorganic and organic sources of fertilizer. Yadav (2000) opined that under a continuous cropping, the decline in yield may either be reversed or minimized by application of complete doses of fertilizer NPK.

Singh et al., (2009a) observed that available phosphorus and potassium were higher in inorganic plots as compared to organic and integrated plots. Application of inorganic NPK alone registered lower NPK uptake at harvest than integrated nutrient management practices (Senthivelu and Prabha, 2007). Chandrakumar et al., (2008) found that continuous application of inorganic fertilizers affected the microbial population and leads to clod formation and reduced the fertility status of the soil by affecting the multiplication of microbial population in soil.

\section{Effect of organic manure on soil health}

Organic manures addition in the soil plant ecosystem is an essential component of sustainability in nutrient exhaustive rice cropping system. It influences the microbial activity in the soil and subsequent nutrient transformation (Kumar and Goh, 2000). Farmyard manure is being used as major source of organic manure in field crops and its role in crop production cannot be overlooked. In addition to supplying all essential nutrients, it increases the activities of bacteria or microbes in soil (Sutaliya and Singh, 2005).

Organic manures are reported to enhance the fertilizers use efficiency and reduce the requirement of inorganic fertilizers. Use of organic manure significantly increased the availability of the limiting nutrients in the soil and maintains the soil fertility in rice (Vats $e t$ al., 2001). Swarnkar et al., (2005) observed that use of green manure, especially Sesbaniarostrata, which nodulates in roots as well as in stems, performed better and maintained the nutrient supply in rice cultivation. 
Ibeawuchi et al., (2006) observed in a degraded soil of Nigeria that poultry manure application increased the residual soil $\mathrm{N}, \mathrm{K}$, $\mathrm{Ca}, \mathrm{Mg}$ and organic matter. Biswas et al., (2007) reported that microbial biomass, carbon and soil organic carbon were responded positively to application of organics (Farmyard manure, Leucaena leucocephala and rice residues) in conjunction with inorganics and also sustained release of nitrogen to the crops in rice-wheat system.

Organic manures improved the soil fertility status and it was pronounced by the dhainchain corporation by increasing organic carbon content $(0.7 \%)$, available soil N (209.6 $\left.\mathrm{kg} \mathrm{ha}^{-1}\right), \mathrm{P}\left(18.6 \mathrm{~kg} \mathrm{ha}^{-1}\right)$ and $\mathrm{K}\left(249.0 \mathrm{~kg} \mathrm{ha}^{-}\right.$ ${ }^{1}$ ) at post-harvest stage (Hemalatha et al., 2000).

Application of organic manures favoured the microbial population, which in turn helped to release bounded or unavailable form of nutrients to available form (Chandrakumar et $a l ., 2008)$. Highest organic carbon (0.84 \%) was also reported in rice by Singh et al., (2009a), when managed organically. Organic carbon and infiltration rate were high with the application of organic manures through press mud, green manure (dhaincha) and green leaf manure under continuous submergence of sodic soil (Singh et al., 2009b).

Sharma et al., (2008) reported that uptake of N, P, K and Zn (85.7, 17.9, 100.8 and $0.60 \mathrm{~kg}$ $\mathrm{ha}^{-1}$ respectively) was maximum under vermicompost application at $3 \mathrm{t} \mathrm{ha}^{-1}$ in rice. Babou et al., (2009) recorded that soils amended with organic manures (FYM at 12.5 $\mathrm{t} \mathrm{ha}^{-1}+$ Panchagavya at $3 \%+$ Amuthakaraisal at $1 \%$ ) consistently registered improved organic carbon, mineral, total $\mathrm{N}$ and grain yield $\left(11257 \mu \mathrm{g} \mathrm{g}^{-1}, 26.33 \mu \mathrm{g} \mathrm{g}^{-1}, 1157 \mu \mathrm{g} \mathrm{g}^{-1}\right.$ and $7.2 \mathrm{t} \mathrm{ha}^{-1}$ respectively) compared to unamended soil (7215 $\mu \mathrm{g} \mathrm{g}^{-1}, 9.21 \mu \mathrm{g} \mathrm{g}^{-1}, 481$ $\mu \mathrm{g} \mathrm{g}^{-1}$ and $2.7 \mathrm{t} \mathrm{ha}^{-1}$ respectively). Under different organic sources, the total and individual population of different microorganisms was higher in wheat straw amendment and was followed by green manure and FYM application in the long-term experiment (Bedi et al., 2009).

Surekha and Rao (2009) opined that addition of nutrients through organic manures and the release of these nutrients from the organics depend on their $\mathrm{C}: \mathrm{N}$ ratio and lignin content. The application of enriched poultry manure compost and composted poultry manure recorded maximum soil available $\mathrm{N}, \mathrm{P}$ and $\mathrm{K}$ as compared to application of recommended NPK fertilizer was reported by Sangeetha et al., (2010).

Sharma and Sharma (2004) found that NPK + FYM showed the highest increase in organic $\mathrm{C}$, available $\mathrm{N}$, available $\mathrm{P}$ and available $\mathrm{K}$ content in soil compared to other inorganic treatments. Datta and Singh (2010) revealed that organic carbon increased from 6.5 to 8.3 $\mathrm{g} \mathrm{kg}^{-1}$ due to application of cattle manure at $10 \mathrm{tha}^{-1}$ in rice - greengram cropping system.

\section{Effect of INM practices on rice}

The concept of integrated nutrient management (INM) seems to sustain the soil fertility through integration of different nutrient sources and their application to produce maximum crop yield per unit input used. Several studies indicated that application of fertilizer $\mathrm{N}$ in conjunction with organic sources is known to stimulate the mineralization and then immobilization of organic $\mathrm{N}$ and reduced the losses of nitrogen.

Integrated nutrient supply is important as a soil ameliorant in alleviating the adverse soil ecological conditions and in improving soil fertility and productivity (Singh et al., 2009a). 


\section{Effect of INM on soil health}

Integrated nutrient management in which both organic manures and inorganic fertilizers are used simultaneously has been suggested as the most effective method to maintain a healthy and sustainable soil system, while increasing crop productivity (Satyanarayana et al., 2002).

Kumar et al., (1999) observed that yield and soil fertility were improved, when organic materials such as green manure at $1.5 \mathrm{t} \mathrm{ha}^{-1}$, groundnut haulm at $3.0 \mathrm{t} \mathrm{ha}^{-1}$ and mustard stover at $5.0 \mathrm{t} \mathrm{ha}^{-1}$ were combined with inorganic fertilizers to supply the recommended amounts of nutrients, while inorganic fertilizers alone did not increase the organic carbon content of the soil.

Integrated nutrient management practices showed significantly higher grain yield (5.77$7.56 \mathrm{t} \mathrm{ha}^{-1}$ ) than chemical fertilization alone $\left(4.32 \mathrm{t} \mathrm{ha}^{-1}\right)$, because of presence of humic acid compounds in soil, which helped in dissolution of minerals and chelation of micronutrients (Raju and Sreenivas, 2008).

Soil analysis for microbial population count at rice harvest stage showed an increase in microbial (actinomycetes, bacteria and fungi) population and soil enzymatic activity under Integrated Plant Nutrient Supply (IPNS) compared to sole chemical fertilizer application (Singh et al., 2006).

Bedi et al., (2009) observed that total microbial population was minimum in the absolute control and maximum, where 50 per cent nitrogen was substituted by wheat straw in the long-term experiment. Integrated nutrient supply is important as a soil ameliorant in alleviating the adverse soil ecological conditions and in improving soil fertility and productivity (Singh et al., 2009a).

\section{Effect of integrating farmyard manure (FYM) on rice}

In a comparative study, Singh et al., (2001) noticed that grain $\left(3.6 \mathrm{t} \mathrm{ha}^{-1}\right)$ and straw $(4.2 \mathrm{t}$ $\mathrm{ha}^{-1}$ ) yields of rice increased due to combined application of 50 per cent recommended NPK + FYM in both shallow and semi-deep water situations over 100 per cent RDF $\left(1.77 \mathrm{t} \mathrm{ha}^{-1}\right)$. Further, they reported that higher yield in the $\mathrm{NPK}+\mathrm{FYM}$ treatment was due to the prolonged availability of plant nutrients. Satheesh and Balasubramanian (2003) inferred that application of FYM at $10 \mathrm{t} \mathrm{ha}^{-1}$ in combination with neem cake at $3.0 \mathrm{t} \mathrm{ha}^{-1}$ found to be equally effective for getting higher grain yield $\left(5.6 \mathrm{t} \mathrm{ha}^{-1}\right)$ and improved nutrient uptake (163.9, 52.4, $133.4 \mathrm{~kg}$ NPK $\mathrm{ha}^{-1}$ ), when compared to application of chemical $\mathrm{N}$ fertilizers alone.

Rao et al., (2004) stated that 50 per cent $\mathrm{N}$ through fertilizer and 50 per cent $\mathrm{N}$ through different organics would have facilitated better photosynthesis activity and promoted the dry matter production. The growth parameters increased significantly by the combined use of fertilizer nitrogen and FYM i.e. 75 per cent recommended dose of nitrogen through urea and 25 per cent recommended dose of nitrogen through FYM (Anny et al., 2005).

Dinesh et al., (2006) reported that highest grain yield with 50 per cent compost +50 per cent NPK source, which was at par with 50 per cent FYM + 50 per cent NPK and both the practices produced significantly higher grain yield over FYM or compost or NPK fertilizer alone. Rice grain yield was significantly higher with the crop receiving 50 per cent $\mathrm{N}$ through chemical fertilizer and 50 per cent $\mathrm{N}$ through FYM followed by the crop receiving 75 per cent $\mathrm{N}$ through chemical fertilizer and 25 per cent $\mathrm{N}$ through FYM (Subhendu and Adhikary, 2005). 
Senthivelu and Prabha (2007) observed that FYM application@12.5 $\mathrm{t} \mathrm{ha}^{-1}$ in combination with the scheduled fertilizer dose of 150:50:50 $\mathrm{kgha}^{-1}$ registered significantly the higher dry matter production (10902 $\left.\mathrm{kg} \mathrm{ha}^{-1}\right)$, grain yield (5538 $\left.\mathrm{kg} \mathrm{ha}^{-1}\right)$ and straw yield $\left(8693 \mathrm{~kg} \mathrm{ha}^{-1}\right)$.

Mankotia et al., (2008) reported that application of FYM at $5 \mathrm{t} \mathrm{ha}^{-1}$ with 100 per cent RDF (90 kg N, $17.4 \mathrm{~kg} \mathrm{P}_{2} \mathrm{O}_{5}$ and $33.3 \mathrm{~kg}$ $\mathrm{K}_{2} \mathrm{O}$ ha $\left.^{-1}\right)$ produced higher grain yield $(5.03 \mathrm{t}$ $\left.\mathrm{ha}^{-1}\right)$ than chemical fertilizers $\left(4.8 \mathrm{t} \mathrm{ha}{ }^{-1}\right)$ alone. In rice, treatment receiving FYM at 12.5 $\mathrm{t} \mathrm{ha}^{-1}+150: 50: 50 \mathrm{~kg} \mathrm{ha}{ }^{-1}$ of NPK recorded higher grain yield $\left(5.5 \mathrm{t} \mathrm{ha}^{-1}\right)$ and straw yield $\left(8.7 \mathrm{t} \mathrm{ha}^{-1}\right)$ than inorganic fertilizers alone (Senthivelu et al., 2009).

Rathi et al., (2008) revealed that the highest grain yield $\left(4.3 \mathrm{t} \mathrm{ha}^{-1}\right)$ and straw yield (5.1 $\left.\mathrm{t} \mathrm{ha}^{-1}\right)$ and NPK uptake (74.6, 21.5, 85.6 $\mathrm{kg} \mathrm{ha}^{-1}$ ) were obtained with 100 per cent recommended dose of inorganic fertilizers in combination with FYM $10 \mathrm{t} \mathrm{ha}^{-1}$. The increased grain yield was mainly due to increased number of tillers hill $^{-1}$, filled grains panicle $^{-1}$ and 1000 grain weight. Highest number of tillers $\mathrm{m}^{-2}$ were recorded when the crop was fertilized with 50 per cent RDF + FYM @ 5 tonnes ha ${ }^{-1}+$ Azotobacter + neem cake@2.5 tonnes ha ${ }^{-1}+\mathrm{PSB} @ 5 \mathrm{kgha}^{-1}$ (Ghulam et al., 2009).

Highest rice productivity $\left(7.1 \mathrm{t} \mathrm{ha}^{-1}\right)$ was obtained with the application of 75 per cent $\mathrm{N}$ supplied through inorganic source and 25 per cent through FYM (Kharub and Chander, 2010).Kumar et al., (2010) observed that the yield attributes viz., number of effective tillers hill $^{-1}$, panicle length, test weight and grain yield $\left(5.7 \mathrm{t} \mathrm{ha}^{-1}\right)$ of rice was higher under 100 per cent recommended dose of NPK fertilizer in combination with FYM at $20 \mathrm{t} \mathrm{ha}^{-1}+$ blue green algae at $10 \mathrm{~kg} \mathrm{ha}^{-1}$.
Gogoi et al., (2010) observed that application of 50 per cent $\mathrm{N}$ through farmyard manure along with 50 per cent of recommended dose of fertilizers (60: 20: 40 NPK kg ha-1) increased the yield attributes such as effective tiller number, panicle length, filled grains panicle ${ }^{-1}$, test weight of seed, grain $\left(4.1 \mathrm{t} \mathrm{ha}^{-1}\right)$ and straw $\left(7.1 \mathrm{tha}^{-1}\right)$ yields.

Chandrapala et al., (2010) observed that application of $300: 17.6: 33.3 \mathrm{~kg} \mathrm{~N}: \mathrm{P}_{2} \mathrm{O}_{5}: \mathrm{K}_{2} \mathrm{O}$ $\mathrm{ha}^{-1}$ and $5 \mathrm{t} \mathrm{ha}^{-1} \mathrm{FYM}$ to rice crop recorded the highest quantity of available soil N, P and K (219:31:246 kg ha $\left.{ }^{-1}\right)$.

Shah and Sandeep (2014) reported that substitution of 50 per cent of NPK through 10 to 15 tonnes of FYM or integrated use of FYM $5 \mathrm{t} \mathrm{ha}{ }^{-1}+$ PSB @ $5 \mathrm{~kg} \mathrm{ha}^{-1}+$ Azotobacter + neemcake @ 2.5 t ha in hybrid rice crop resulted into higher productivity of hybrid rice over application of 100 per cent NPK through chemical fertilizers.

\section{Effect of FYM soil fertility and nutrient uptake}

The highest values of $\mathrm{N}$ uptake (49.0 $\mathrm{kg} \mathrm{ha}^{-1}$ ) were observed in rice with application of NPK (80: 50: $50 \mathrm{~kg} \mathrm{ha}^{-1}$ ) + FYM at $10 \mathrm{t} \mathrm{ha}^{-1}$ (Sengar et al., 2000). Sharma and Sharma (2004) recorded the increase in organic carbon and available $\mathrm{N}, \mathrm{P}$ and $\mathrm{K}$ contents in soil due to combined application to FYM and inorganic fertilizers.

Application of NPK fertilizer in combination with FYM registered the higher uptake of $\mathrm{N}$, $\mathrm{P}$ and $\mathrm{K}$ by both grain and straw (Natarajan $e t$ al., 2005). The maximum nutrient uptake (154.2, 24.8 and $171.6 \mathrm{~kg}$ NPK ha ${ }^{-1}$ ) at harvest stage was noticed with FYM at $12.5 \mathrm{t}$ $\mathrm{ha}^{-1}$ with RDF than inorganic fertilizers alone (Senthivelu et al., 2009). Application of 100 $\mathrm{kg}$ of $\mathrm{N}$ along with FYM at $10 \mathrm{t} \mathrm{ha}^{-1}$ recorded 
the highest uptake of 135.5, 29.47 and 144.53 $\mathrm{kg} \mathrm{ha}{ }^{-1}$ of NPK in rice (Goud and Konde, 2009). Kalaiyarasi (2009) found that application of FYM and biofertilizers along with the recommended chemical fertilizer enhanced the microbial consortia, improved the root biomass and root colour from black to brown and brown to white.

Chandrapala et al., (2010) observed that application of NPK at 300:17.6:33.3 $\mathrm{kg} \mathrm{ha}^{-1}$ and $5 \mathrm{t} \mathrm{ha}^{-1}$ FYM to rice crop recorded the highest quantity of available soil $\mathrm{N}, \mathrm{P}$ and $\mathrm{K}$ (219:31:246 $\mathrm{kg} \mathrm{ha}^{-1}$ ) after crop harvest and this might be due to the slow release of nutrients from FYM and also due to chelating effect of FYM.

Bhowmick et al., (2011) found that higher yields under combined use of RDF and FYM could be attributed to well decomposition of FYM, which favoured better nutrient availability coupled with higher assimilation of nutrients. Organic carbon content of surface soil increased significantly with integrated use of FYM and $\mathrm{Zn}$ fertilizers over control (Vipin et al., 2011).

Nayak et al., (2012) found that the application of inorganic fertilizer along with FYM significantly increased the available NPK and micronutrient content of soil, which was followed by application of inorganic fertilizer alone resulted with increase in NPK but slight decline in micronutrient contents viz., Zn, Fe, $\mathrm{Cu}$ and $\mathrm{Mn}$. Thus, application of inorganic fertilizer along with FYM is an effective way of sustaining soil properties in subtropical paddy soils.

Relatively more nitrogen, phosphorus and potassium uptake by hybrid rice crop was recorded from the plot in which NPK 50 per cent RDF+ neem cake@ 2.5 t ha ${ }^{-1}$ +FYM @ $5 \mathrm{t} \mathrm{ha}^{-1}+$ Azotobacter+ PSB @ $5 \mathrm{~kg} \mathrm{ha}^{-1}$ was applied as reported by Shah and Sandeep
(2014). Higher N, P and K uptake by grain and straw (56.0 and $26.7 \mathrm{~kg} \mathrm{ha}^{-1}$ respectively) was observed with the application of FYM @ $10 \mathrm{t} \mathrm{ha}^{-1}+100$ percent RDF but was comparable with the treatment of 100 percent of RDF alone (Ranjitha and Reddy, 2014).

\section{Effect of integrating green leaf manure (GLM) on rice}

Green leaf manuring was better than FYM and this difference was reflected in all the growth and yield attributes, and consequently yield increase with GLM over FYM was 9.9 to 10.1 per cent. Presumably, the faster decomposition of GLM by soil microbes release more $\mathrm{CO}_{2}$, speeds up chemical reaction and improve the nutrient availability (Jeyajothi and Nalliah Durairaj, 2015).

Chapale and Badole (1999) reported that significantly higher grain $\left(52.08 \mathrm{q} \mathrm{ha}^{-1}\right)$ and straw (83.28 $\left.\mathrm{q} \mathrm{ha}^{-1}\right)$ yields were recorded under Glyricidia foliage @ 5t ha ${ }^{-1}$ over the control. Raju and Reddy (2001) reported that incorporation of Glyricidia lopping ( $5 \mathrm{t} \mathrm{ha}^{-1}$ ) with recommended dose of NPK resulted in 15.4 per cent yield increase and recorded higher B:C ratio (2.10) as compared to application of 100:50:50 kg NPK ha-1 (1.40).

Gill et al., (2008) stated that integrated nutrient management with green manuring as a substitute saved 50 per cent of the chemical fertiliser, with an average productivity of rice $\left(4.8 \mathrm{t} \mathrm{ha}^{-1}\right)$ and wheat $\left(3.3 \mathrm{tha}^{-1}\right)$ in rice-wheat system. Urkurkar et al., (2010) reported that among the different sources of nitrogen substitution, the highest yield of rice $(6.3$ $\mathrm{t} \mathrm{ha}^{-1}$ ) were obtained with the 50 per cent of $\mathrm{N}$ substituted through green manures.

Application of 50 per cent recommended dose

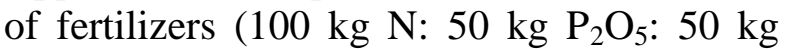
$\mathrm{K}_{2} \mathrm{O}$ ha $^{-1}$ ) along with 50 per cent $\mathrm{N}$ substitution through Glyricidia to rice 
recorded higher grain yield $\left(7.2 \mathrm{t} \mathrm{ha}^{-1}\right)$ than inorganic fertilizers $\left(6.8 \mathrm{t} \mathrm{ha}^{-1}\right)$ alone (Talathi et al., 2009b). Rao et al., (2004) observed that the highest grain yield $\left(5.9 \mathrm{t} \mathrm{ha}^{-1}\right)$ was recorded with the combination of 50 per cent $\mathrm{N}$ each through fertilizers and Glyricidia leaf manure in rice.

Yadav et al., (2007) revealed that application of 100 per cent RDF of 80:50:50 N: $\mathrm{P}_{2} \mathrm{O}_{5}: \mathrm{K}_{2} \mathrm{O}$ $\mathrm{kg} \mathrm{ha}^{-1}$ along with Glyricidia at $10 \mathrm{tha}^{-1}$ in rice recorded the highest panicle weight (3.5 g), grain yield $\left(3.4 \mathrm{t} \mathrm{ha}^{-1}\right)$, straw yield $(3.9 \mathrm{t}$ $\mathrm{ha}^{-1}$ ) and biological yield $\left(7.3 \mathrm{t} \mathrm{ha}^{-1}\right)$. Kamble et al., (2008) revealed that incorporation of Glyricidia and poultry manure at $5 \mathrm{t} \mathrm{ha}^{-1}$ produced higher grain yield $\left(5.2 \mathrm{t} \mathrm{ha}^{-1}\right)$ than Glyricidia and poultry manure at $2.5 \mathrm{t} \mathrm{ha}^{-1}$ and control in rice.

\section{Effect of GLM on soil health and nutrient uptake of rice}

Halepyati and Sheelavantar (1993) reported that $\mathrm{N}$ substitution with green leaf manure in rice production gave significantly higher $\mathrm{N}$ uptake. The organic carbon status of soil $(1.33 \%)$ enhanced by application of 50 per cent $\mathrm{N}$ through chemical fertilizers along with 50 per cent N through Sesbania rostrata than initial level $(0.71 \%)$ was reported by Raju and $\operatorname{Reddy}(2000)$.

Kaleeswari et al., (2012) stated that green leaf manuring increased the N, P and K uptake by grain. Saravanapandian (2009) opined that the combined application of manures and fertilizer also significantly influenced the uptake of $S$ by the rice crop. The highest $S$ uptake was registered with the application of GLM with N, P and K fertilizer.

Talathi et al., (2009a) reported that the N, P and $\mathrm{K}$ uptake was higher with application of glyricidia (99.6, 27.6 and $82.6 \mathrm{~kg} \mathrm{ha}{ }^{-1}$ respectively) in conjunction with chemical fertilizers compared to control in hybrid rice. Sunitha et al., (2010) found that application of 50 per cent $\mathrm{N}$ through urea +25 per cent $\mathrm{N}$ through green leaf manure (Glyricidia maculata) +25 per cent $\mathrm{N}$ through FYM + Azospirillum recorded the highest availability, concentration and uptake of nutrients at all the stages of rice growth over other treatments during kharif in sandy loam soil.

\section{Effect of integrating vermicompost (VC) on rice}

Jeyabal and Kuppuswamy (2001) opined from a rice-legume study that the integrated application of 50 per cent $\mathrm{N}$ through vermicompost, 50 per cent through fertilizers $\mathrm{N}$ and biofertilizers recorded 12.2 and 19.9 per cent higher grain yield in rice and legume (6.25 and $0.50 \mathrm{t} \mathrm{ha}^{-1}$, respectively) than those obtained with 100 per cent fertilizers $\mathrm{N}$ alone.

The yield increase was 10.8 per cent with judicious use of vermicompost and inorganic fertilizer enabled rice plant to assimilate sufficient photosynthates resulting in increased drymatter production and these together produced more productive tillers, panicle and number of filled grains leading to higher grain yield (Mondal et al., 2003).

Application of vermicompost favourably influenced the growth of rice (Meena, 2003; Anitha and Prema, 2003) and improved the yield components and yield in rice (Sudhakar et al., 2002). Norman et al., (2005) reported that vermicompost application improved plant growth of rice.

The combined application of fertilizer $\mathrm{N}$, vermicompost and azolla sustained the productivity even at lower rate of $\mathrm{N}$ fertilizer application (Singh et al., 2005). Barik et al., (2006) reported that application of 50 per cent $\mathrm{RDN}$ in combination with vermicompost at 
$10 \mathrm{t} \mathrm{ha}^{-1}$ significantly improved the growth and yield attributes of rice compared with the application of 100 per cent RDN and of different combinations of FYM and mineral fertilizers. The highest grain and straw yields were recorded when crop was supplied with 50 per cent RDN along with $10 \mathrm{t}$ vermicompost ha ${ }^{-1}$. Maximum grain and straw yield recorded with the application of 50 per cent RDN through urea +50 per cent RDN through vermicompost and was found to be significantly superior over the rest of the treatments, which was followed by the treatment received 100 per cent RDN through urea (Viraktamath, 2006).

Application of vermicompost at $3.0 \mathrm{t} \mathrm{ha}^{-1}$ produced taller plants, leaf area index and dry weight hill ${ }^{-1}$ than FYM at $10 \mathrm{t} \mathrm{ha}^{-1}$ in rice. These better growth attributes in rice under vermicompost was due to increased availability of plant nutrients as reported by Sharma et al., (2008). Singh et al., (2009a) reported that 25 to 50 per cent NPK can be substituted by FYM, vermicompost or FYM along with vermicompost in rice. Yield reduction of rice by substitution of 25 per cent NPK through FYM, vermicompost, press mud and 50 per cent by FYM + vermicompost over 100 per cent NPK were 2.5, 1.5, 6.3 and 7.3 per cent respectively.

Paramesh et al., (2014) reported that 50 per cent RDN through chemical fertilizers +50 per cent RDN through vermicompost recorded significantly higher plant height, leaf area, number of tillers hill ${ }^{-1}$, total dry matter accumulation hill ${ }^{-1}$, grain yield (39.48 q ha-1) and straw yield (52.9 $\left.\mathrm{q} \mathrm{ha}^{-1}\right)$.

Ramalakshmi et al., (2012) found that 125 per cent $\mathrm{RDF}+5 \mathrm{t} \mathrm{ha}^{-1}$ vermicompost increased the number of panicles, panicle length, panicle weight, 1000 grain weight, grain yield, straw yield and protein content. Kandeshwari et al., (2012) revealed that integrated nutrient management practices involving vermicompost recorded the highest grain yield $\left(5.8 \mathrm{t} \mathrm{ha}^{-1}\right)$ than 100 per cent inorganic fertilizers $\left(5.17 \mathrm{t} \quad \mathrm{ha}^{-1}\right)$. Jagadeeshwar et al., (2012) reported that the application of vermicompost could not only help realise higher grain yield but also to minimize problem due to biotic stresses under organic rice cultivation.

\section{Effect of VC on soil fertility and nutrient uptake}

Kale et al., (1987) observed an increase in the rates of nutrients uptake with the increase in symbiotic microbial association in cereal and ornamental plants on using vermicompost as a source of organic manure. Kale and Bano (1988) opined that nutrient uptake of rice was enhanced with 50 per cent of RDF and $2.5 \mathrm{t}$ $\mathrm{ha}^{-1}$ of vermicompost application than 100 per cent RDF, apart from increasing grain and straw yields of upland paddy.

Kale et al., (1992) observed that there was an increase in all the groups of microbes, except actinomycetes due to the application of vermicompost in place of FYM and other chemical fertilizers. They further noticed that total $\mathrm{N}$ content in vermicompost and FYM plots was almost same. Albanel et al., (1998) reported that earthworms accelerated the mineralization rate and converted the wastes into casting with higher nutritional value.

From a rice-legume study, Jeyabal and Kuppuswamy (2001) found that vermicompost when applied in combination with chemical fertilizers increased the $\mathrm{N}, \mathrm{P}$ and $\mathrm{K}$ uptake by 15.3, 10.7 and 9.4 per cent respectively in rice over $\mathrm{N}$ fertilizer alone.

Lal et al., (2003) stated that vermicompost contain major and minor plant nutrients in available form that in turn improved the uptake of nutrients by the plants. 
The application of vermicompost enhanced the availability of nutrients in the soil and uptake by the plants (Ushakumari et al., 2006).

Sharma et al., (2008) reported that uptake of N, P and $\mathrm{K}$ and $\mathrm{Zn}(85.7,17.9,100.8$ and 0.60 $\mathrm{kg} \mathrm{ha} \mathrm{ha}^{-1}$ respectively) was maximum under vermicompost application at $3 \mathrm{t} \mathrm{ha}^{-1}$ in rice. Arun et al., (2014) found that 125 per cent $\mathrm{RDF}+5 \mathrm{t} \mathrm{ha}^{-1}$ vermicompost increased $\mathrm{P}$ and $\mathrm{K}$ uptake in grain and straw over control. Application of organic manures alone and integrated nutrient management increased the available $\mathrm{N}, \mathrm{P}$ and $\mathrm{K}$ content of soil as compared to recommended dose of fertilizer treated plots (Venkatakrishnan and Ravichandran, 2012).

\section{Effect of integrating poultry manure (PM) on rice}

Nasimul Gani (2014) stated that mixing poultry litter with chemical fertilizer enhances the yield of crop and soil fertility and also minimizes the cost of fertilizer. Amujoyegbe and Alofe (2003) reported that the integrated use of poultry manure and inorganic fertilizer increased yield and quality of cowpea by increasing crude protein content, percentage of crude fibre, total nitrogen and carbohydrate contents.

Adeniyan and Ojeniyi (2003) studied the comparative efficiency of residual effects of poultry manure and concluded that poultry manure with inorganic fertilizer gave residual effects on soil chemical composition and increased plant height, leaf area, dry matter yield, nutrient uptake and grain yield of maize significantly compared to the application of inorganic fertilizer alone. Application of 50 per cent $\mathrm{N}$ through composted poultry manure and 50 per cent $\mathrm{N}$ through green leaf manure recorded significantly higher yield characteristics of rice, when compared to recommended dose of NPK through fertilizers (Yadav et al., 2006).

Mukharjee et al., (2006) conducted an experiment and revealed that maximum seed yield of rice bean $(1.51 \mathrm{t} / \mathrm{ha})$ was recorded, when the crop received 50 per cent recommended dose of nutrients applied through chemical fertilizer along with another 50 per cent recommended dose of nutrients through poultry manure. Setty et al., (2007) observed that application of 50 per cent recommended dose of 100: 50:50 kg N: $\mathrm{P}_{2} \mathrm{O}_{5}$ : $\mathrm{K}_{2} \mathrm{O} \mathrm{kg} \mathrm{ha}{ }^{-1}$ through poultry manure recorded higher plant height $(76.3 \mathrm{~cm})$, total number of tillers (46.0), LAI (4.7), total dry matter $\left(165.3 \mathrm{~g} \mathrm{hill}^{-1}\right)$, effective tillers hill ${ }^{-1}$ (35.9), filled grains panicle ${ }^{-1}$ (271.9), lower percentage of chaffiness $(7.4 \%)$ and higher grain and straw yield (8.3 and $\left.8.6 \mathrm{t} \mathrm{ha}^{-1}\right)$.

Rathiya et al., (2007) established a field experiment to study the effect of different organic amendments (farmyard manure, poultry manure and bio fertilizer) combined with different chemical fertilizer rates on the growth and yield parameters of sunflower. Behera et al., (2007) conducted a study and concluded that grain yield of wheat was significantly increased with 50 per cent NPK+ poultry manure at $2.5 \mathrm{t} /$ ha compared to other INM treatments.

\section{Effect of PM on soil fertility and nutrient uptake}

Rasnake et al., (2000) reported that poultry litter can serve as an economical source of nutrients for crop production. However, repeated use of litter lead to an accumulation of phosphorus, copper and zinc in the surface soil layer. This study indicated that applying manure to soils will supply the nutrient needs of crops. Lopez et al., (2001) reported that poultry manure improved chemical and physical properties of soil and the products 
obtained were ecologically healthy. Saha et al., (2008) conducted a field study on the effect of combined application of in-organic fertilizer, and organic manure on the productivity, mineral nutrition and soil properties and post-harvest soil analysis showed that the soil fertility status was enriched in respect of organic carbon, available N,P and K, where inorganic fertilizer was incorporated in association with poultry manure over the 100 per cent NPK through chemical fertilizer.

Maguire et al., (2006) carried out an experiment with different level of poultry litter to assess the bacteria population in soil. They reported that application of poultry litter to soil increased the bacteria population, which is also responsible for soil fertility. Shelke et al., (2001) investigated the effect of farmyard manure and poultry manures and revealed that poultry manures with urea increased yield quality and the enrichment of soil nutrient $\mathrm{N}, \mathrm{P}, \mathrm{K}, \mathrm{Ca}, \mathrm{Mg}, \mathrm{Cu}$ and $\mathrm{Zn}$.

Addition of organic manures can compensate the detrimental effects on soil health due to injudicious application of chemical fertilizers. Whereas, excessive application of chemical fertilizers suppresses the soil productivity and harm the environment. Therefore, integrated nutrient management practices are well suited but need to be quantified either 25 or 50 per cent on equivalent basis. Further, suitability of organic manures can be based on local availability or trial based for precise results as soil types and environment play as a major factor and varies from place to place.

\section{References}

Adeniyan, O.N. and S.O. Ojeniyi, 2003. Comparative effectiveness of different levels of poultry manure with NPK fertilizer on residual soil fertility, nutrient uptake and yield of maize. Moor Journal of Agricultural Research, 4 (2):191-197.
Albanel, E., J. Plaixats and T. Cabrero. 1998. Chemical changes during vermicomposting (Eisenia fetida) of sheep manure mixed with cotton industrial wastes. Biology and Fertility of Soils, 6: 266-269.

Amujoyegbe, B.J. and C.O. Alofe , 2003. Influence of poultry manure and inorganic fertilizer on grain yield and proximate composition of 2 cultivars of cow pea (Vigna unguiculata L. Walps). Moor Journal of Agricultural Research, 4 (1): 37-45.

Anitha.S and A. Prema. 2003. Vermicompost boosts crop production. Indian Farming, 52 (20): 15- 18.

Anny Mrudhula, K., A. Ravikumar, Ch. PullaRao and K. Chandrashekar. 2005. Productivity and uptake of rice as affected by integrated use of nitrogen. Andhra Agriculture Journal,52 (2): $1-4$.

Arun, R., N. Meena, LaljiYadav and K. Gilotia. 2014. Effect of organic and inorganic sources of nutrient on yield, yield attributes and nutrient uptake of rice. Bio Scan, 9 (2): 595597.

Babou, C., G. Poyyamoli and B. Guna. 2009. Impact of LEISA based System of Rice Intensification (SRI) practices on rice grain yield and soil properties in rice - rice - rice cropping system in Puducherry region. International Journal of Agricultural Sciences, 5 (1): 43-45.

Barik, A., K. Arindam Das, A.K. Giri and G.N. Chattopadhyay. 2006. Effect of organic (Vermicompost, farmyard manure) and chemical sources of plant nutrients on productivity and soil fertility of Kharif rice (Oryzasativa L). Crop Research, 31 (3): 339-342.

Basumatary, B. and M.C. Talukdar.1998. Long term effect of integrated nutrient supply system on soil property Inceptisol of Assam. Oryza, 35 (1): 43-46.

Bedi, P., Y.P. Dubey and N. Datt. 2009. Microbial properties under rice -wheat cropping sequence in an acid alfisol. Journal of Indian Society of Soil Science, 57 (3): 373-377.

Behera, U.K., A.R.Sharma and H.N Pandey, 2007. Sustaining productivity of wheat soybean cropping system through integrated nutrient management practices on the Vertisol of central India. Plant and soil, 297 (2): 185- 
199.

Bhowmick, M., K. Dhara, M.C. Bag, M.K. Adhikari and B. Kundu. 2011. Integrated nutrient management for aromatic rice in West Bengal. Oryza,48(3): 276-277.

Biswas, H., R.K. Rattan and A.K. Singh. 2007. Effect of soil manipulation and resource management on carbon and nitrogen turnover under rice - wheat cropping system. Journal of Indian Society of Soil Science, 55 (3): 276-284.

Chandrakumar, H.L., C.T.A. Kumar, N.G. Kumar, A. K. Chakravarthy and T. B. Puttaraju. 2008. Effect of organic sources of nutrients on soil microbes. Journal of Soil Biology and Ecology, 28 (2): 186-189.

Chandrapala, A.G., M. Yakadri, R.M. Kumar and G.B. Raj. 2010. Productivity and economics of rice (Oryza sativa) - maize (Zea mays) as influenced by methods of crop establishment, $\mathrm{Zn}$ and $\mathrm{S}$ application in rice. Indian Journal of Agronomy, 55 (3): 171-176.

Chandrapala, A.G., M. Yakadri, R.M. Kumar and G.B. Raj. 2010. Productivity and economics of rice (Oryza sativa) - maize (Zea mays) as influenced by methods of crop establishment, $\mathrm{Zn}$ and $\mathrm{S}$ application in rice. Indian Journal of Agronomy, 55 (3): 171-176.

Chapale, S.D. and W.P. Badole. 1999. Effect of green manuring and NPK combinations on soil health and yield of rice. Indian Journal of Agronomy, 44 (3): 448-451.

Datta, M. and N.P. Singh. 2010. Nutrient management in rice-based cropping systems as influenced by applying cattle manure alone or in combination with fertilizers in upland acid soils of Tripura. Journal of Indian Society of Soil Science, 58 (1): 94-98.

Dinesh, M.K., Y.S. Shivay and B.N. Mishra. 2006. Field evaluation of System of Rice Intensification (SRI) and Conventional Rice Culture (CRC) with organic and inorganic sources of nutrients in north India. In: National symposium on "System of rice intensification (SRI) - present status and future prospects" $17-18^{\text {th }}$ November. p.96.

Ghulam, A., M.Q. Khan, J. Muhammad, T. Muhammad and H. Farida. 2009. Nutrient uptake, growth and yield of wheat affected by zinc application rates. International Journal of Agriculture and Bioogy, 11 (4): 389-396.
Gill, M.S., S.S. Pal and I.P.S. Ahlawat. 2008. Approaches for sustainability of rice (Oryza sativa)-wheat (Triticum aestivum) cropping system in Indo - gangetic plains of India -A Review. Indian Journal of Agronomy, 53 (2): 81-96.

Gogoi, B., N.G. Barua and T.C. Baruah. 2010. Effect of integrated nutrient management on growth, yield of crops and availability of nutrients in inceptisol under rainfed rice (Oryza sativa) - niger (Guizotia abyssinica) sequence of Assam. Indian Journal of Agricultural Sciences, 80 (9): 824-828.

Goud, V.V. and N.M. Konde. 2009. Influence of conjunctive use of FYM and inorganic fertilizers on yield, nutrient uptake, economics and soil fertility in rice-mustard sequence. Green Farming, 2 (2): 1005-1007.

Halepyati, A.S. and M.N. Sheelavantar. 1993. Effect of incorporation of different densities of Sesbania rostrata and nitrogen substitution rates on growth and yield of rice. Oryza, 30 (1): 67-72.

Hemalatha, M., V. Thirumurugan and R. Balasubramanian. 2000. Effect of organic sources of nitrogen on productivity, quality of rice (Oryza sativa) and soil fertility in single crop wetlands. Indian Journal of Agronomy, 45 (3): 564-567.

Ibeawuchi, I.I., E.U. Onweremadu and N.N. Oti. 2006. Effect of poultry manure on green (Amaranthus cruentus) and water leaf (Talinum triangulare) on degraded ultisols of Owerri south-eastern Nigeria. Journal of Animal Veterinary Advances, 5 (1): 53-56.

Jagadeeshwar, R., N. RamagopalaVarma, B. Gopal Reddy, P. Narsimha Reddy, C.H. Surdender and S. Vanishree. 2012. Evaluation of different organic nutrient sources and varieties for organic rice (Oryza sativa L.) production. Journal of Research ANGRAU, 40 (3): 6-8.

Jeyabal, A. and G. Kuppuswamy. 2001. Recycling of organic wastes for the production of vermicompost and its response in rice legume cropping system and soil fertility. European Journal of Agronomy, 15: 153-170.

Jeyajothi, R. and S. Nalliah Durairaj. 2015. Influence of integrated nutrient management practices on yield and yield attributes, and economics of transplanted Rice (Oryza ativa) 
in South Zone of Tamil Nadu. International Journal of Innovative Research Science and Technology,1(11): 462-466.

Kalaiyarasi, D. 2009. Studies on stand establishment techniques and nutrient management practices in wet seeded lowland rice. M.Sc. (Ag.) Thesis, Tamil Nadu Agricultural University, Coimbatore, Tamil Nadu, India.

Kale, R.D. and K. Bano. 1988. Earthworm cultivation and culturing techniques for production of vermicompost. Mysore Journal of Agricultural Sciences, 22 (1): 339-344.

Kale, R.D., K. Bano, M.N. Sreenivasa, K. Vijayak and D.J. Bagayaraj. 1992. Incidence of cellulolytic and lynolytic organisms in the earthworm worked soils. Soil Biology and Biochemistry, 24: 1317-1320.

Kale, R.D., M.N. Sreenivasa and D.J. Bagyaraj. 1987. Influence of worm cast on the growth and mycorrhizal colonization of two ornamental plants. South Indian Horticulture, 35: 433-437.

Kaleeswari, R.K., S. Maragatham and M.R. Latha, 2012. Direct and residual effect of Phosphorus sources and manures on yield and nutrient uptake by rice in Alfisol. Madras Agricultural Journal, 99 (3): 37-39.

Kamble, R., A.C. Sawant, P.G. Chavan and P.P. Pawar. 2008. Effect of integrated nutrient management on yield, and $\mathrm{N}, \mathrm{P}$ and $\mathrm{K}$ uptake by hybrid rice (RTNRH-6). International Journal of Agricultural Sciences,4 (2): 710711.

Kandeshwari, M., S. Jeyaraman and N. Thavaprakash. 2012. Evaluation of integrated nutrient management practices under system of rice intensification: In. International Symposium on 100 years of Rice Science and looking beyond. pp. 523-524.

Kharub, A.S. and S. Chander. 2010. Integrated plant nutrient supply in rice (Oryza sativa) wheat (Triticum aestivum) system. Indian Journal of Agricultural Sciences, 80 (4): 282286.

Kumar, K. and K.M. Goh. 2000. Crop residue management: Effects on soil quality and soil $\mathrm{N}$ dynamics, crop yield and $\mathrm{N}$ recovery. Advances in Agronomy,68: 197-319.

Kumar, N., K.K. Chandra and R. Singh. 2010. IPNS on growth, yield and economics of rice.
Indian Journal of Fertilizers, 6 (2): 25-28.

Kumar, V., B.C. Ghosh and R. Bhat. 1999. Recycling of crop wastes and green manure and their impact on yield and nutrient uptake of wetland rice. Journal of Agricultural Science, 132: 149 -154.

Lal, O.P., Y.N. Srivastava and S.R. Sinha. 2003. Vermicomposting. Indian Farming, 52 (12): 6-8.

Lopez, R., N. Jeffers, J. Machuka and Castillo, 2001.The fermented manures, an ecological alternative for the production of vegetables in organoponicos Guantanamo Cuba. In: Conservation Agriculture, a Worldwide Challenge, First World Congress on Conservation Agriculture, Madrid, Spain, 2: 369-374.

Maguire, R.O., D. Hesterberg, A. Gernat, K. Anderson, M. Wineland and J. Grimes, 2006. Liming poultry manures to decrease soluble phosphorus and suppress the bacteria population. Journal of Environment Quality, 35: 849-857.

Mankotia, B.S., J. Shekhar, R.C. Thakur and S.C. Negi. 2008. Effect of organic and inorganic sources of nutrients on rice (Oryza sativa) wheat (Triticum aestivum) cropping system. Indian Journal of Agronomy, 53(1): 32-36.

Meena, K.C. 2003. Vermiculture in relation to organic farming. Indian Farming, 52 (12): 2730.

Mondal, S.S., SitamgshuSarkar, Aruoghosh and J. Das. 2003. Response of summer rice (Oryza sativa L.) to different organic and inorganic sources of nutrients. Crop Research, 25: 219222.

Mukharjee, A.K., S. Maiti, M.K.Nanda and Nandi Modhumita, 2006. Productivity of rice bean as affected by chemical fertilizer and poultry litter, Journal of Crop and Weed, 2 (2): 3436.

NasimulGani. 2014. Impact of poultry litter on soil properties and production of jute. Ph.D. Thesis, University of Dhaka - 1000, Bangladesh.

Natarajan, S., G. Kuppuswamy, K. Arivazhagan and K. Thirukumaran. 2005. Effect of organic manure application in rice. Oryza, 42(4): 319320.

Nayak, A.K., A.K. Shukla, Mohammad Shahid and Rahul Tripathi. 2012. International 
Symposium on 100 years of Rice Science and Looking Beyond,2: 541-542.

Norman, Q.A., A.G. Paola and A.E. Clive. 2005. Suppression of insect pest populations and damage to plants by vermicomposts. Bioresources Technology, 96: 1137-1142.

Paramesh, V., C.J. Sridhara, K.S. Shashidhar and S. Bhuvaneswari. 2014. Effect of integrated nutrient management and planting geometry on growth and yield of aerobic rice. International Journal of Agricultural Sciences, 10: 49 -52.

Prasad, B., J. Prasad and R. Prasad. 1995. Nutrient management for sustained rice and wheat production in calcareous soil amended with green manures, organic manure and zinc. Fertilizer News, 40 (3): 39-41.

Prasad, R., S.N. Sharma, S. Singh and R. Lakshmanan. 1992. Agronomic practices for increasing nitrogen use efficiency and sustained crop production. In: National Symposium for "Resource Management for Sustained Production", 25-28 February, Indian society of Agronomy, Rajasthan Agricultural University. pp.8.

Raju, R.A. and Ch. Sreenivas. 2008. Agronomic evaluation of system of rice intensification methods in Godavari delta. Oryza, 45 (4): 280-283.

Raju, R.A. and M.N. Reddy. 2000. Sustainability of productivity in rice (Oryza sativa) - rice sequential cropping system through integrated nutrient management in coastal ecosystem. Indian Journal of Agronomy, 45 (3): 447-452.

Raju, R.A. and M.N. Reddy. 2001. Response of hybrid and conventional rice to Glyricidia lopping, sulphur and zinc application. Fertilizer News, 46 (11): 61-62.

Ramalakshmi, C.H.S., P.C. Rao, T. Sreelatha, M. Mahadevi, G. Padmaja, P.V. Rao, and A. Sireesha. 2012. Nitrogen use efficiency and production efficiency of rice under rice-pulse cropping system with integrated nutrient management. Journal of Rice Research, 5 (2): 42-51.

Ranjitha, P. and K.I. Reddy. 2014. Effect of different nutrient management options on rice under SRI method of cultivation. Indian Journal of Agronomy, 51 (4): 277-290.

Rao, U.V., Y.R. Ramu, C.R. Kumari and C.R. Reddy. 2004. Effect of organic and inorganic sources of nitrogen on growth, yield, nitrogen uptake and economics of lowland rice. Madras Agricultural Journal, 91 (12): 389393.

Rao, U.V., Y.R. Ramu, C.R. Kumari and C.R. Reddy. 2004. Effect of organic and inorganic sources of nitrogen on growth, yield, nitrogen uptake and economics of lowland rice. Madras Agricultural Journal, 91 (12): 389393.

Rasnake, M., F.Sikora and L. Murdock.2000. Nutrient accumulation and movement in soils

following the use of poultry litter, animal agricultural and food processing wastes, Proc. of the Eighth International Symposium, DesMoines, Iowa, USA, 9-11, pp: 562-567.

Rathi, A.S., R.P. Singh and V. Kumar. 2008. Effect of integrated nutrient management on productivity and nutrient uptake in transplanted rice. Indian Farmers Digest, 31 (2): 114-117.

Rathiya, G.R., R.N.Singh, T.Chowdhury and S.P.Tiwari. 2007. Effect of different organic sources in combination with different dozes of chemical fertilizer on the growth and yield parameters of sunflower hybrid MSFH-17. Plant Archives, 7 (2): 869-870.

Saha, A.R., D.N. Maitra, B. Majumder, S. Saha and S. Mitra, 2008. Effect of integrated nutrient management on roselle (Hibiscas sabdariffaL.) productivity, its mineral nutrition and soil properties, Indian Journal of Agricultural Sciences, 78 (5): 418-421.

Sangeetha, S.P., A. Balakrishnan and J. Bhuvaneswari. 2010. Organic nutrient sources on growth and yield of rice. Madras Agricultural Journal, 97 (9): 251-253.

Saravanapandian. 2009. Long term manure and fertilizer addition on adsorption and desorption of phosphorus under rice monoculture. Madras Agricultural Journal,96 (12): 325-330.

Satheesh, N. and N. Balasubramanian. 2003. Effect of organic manure on yield and nutrient uptake under rice-rice cropping system. Madras Agricultural Journal, 90 (3): 41-46.

Satyanarayana, V., V.P.V. Prasad, V.R.K. Murthy and K.J. Boote. 2002. Influence of integrated use of farmyard manure and inorganic fertilizers on yield and yield components of 
irrigated lowland rice. Journal of Plant Nutrition, 25 (10): 2081-2090.

Sengar, S.S., L.J. Wade, S.S. Baghel, R.K. Singh and G. Singh. 2000. Effect of nutrient management on rice (Oryza sativa) in rainfed lowland of Southeast Madhya Pradesh. Indian Journal of Agronomy, 45 (2): 315- 322.

Senthivelu, M. and A.C.S. Prabha. 2007. Studies on nutrient uptake, post-harvest nutrient availability and nutrient balance sheet under integrated nutrient management practices in wet seeded rice. Asian Journal of Soil Science, 2 (1): 33-39.

Senthivelu, M., B.J. Pandian and A.C.S. Prabha. 2009. Dry matter production and nutrient removal in wet seeded rice-cotton cropping sequence under integrated nutrient management practices. Oryza, 46 (4): 279289.

Setty, T.K.P., A.G. Bandi, S. Singh and M.T. Sanjay. 2007. Influence of integrated nutrient management on growth and yield of hybrid rice under System of Rice Intensification (SRI) and aerobic method of cultivation. In: $2^{\text {nd }}$ National Symposium on SRI, Agartala, Tripura. pp. 82-84.

Shah, R.A., and D.R. Sandeep. 2014. Effect of integrated nutrient management on vegetative growth and yield of transplanted hybrid rice. International Journal of Agricultural and Crop Science, 7 (11): 863-869.

Sharma, D.K., K. Prasad and S.S. Yadav. 2008. Effect of nutrient management on the performance of dwarf scented rice (Oryza sativa L.) grown in rice - wheat sequence. International Journal of Agricultural Sciences, 4 (2): 660 - 662.

Sharma, S.N. and S.K. Sharma. 2004. Role of crop diversification and integrated nutrient management in resilience of soil fertility under rice - wheat cropping system. Archives of Agronomy and Soil Science, 50 (3): 345352.

Shobarani, N., G.S.V. Prasad, A.S.R. Prasad, B. Sailaja, P. Muthuraman, S. Numeera and B.C. Viraktamath. 2010. Rice Almanac India. In: Technical Bulletin No 5, DRR, Rajendranagar, Hyderabad. pp 6-7.

Singh, D.K., B.S. Mahapatra, S. Gupta and R. Singh. 2009a. Impact of nutrient management practices in rice based cropping system on productivity and soil health. Journal of Eco friendly Agriculture, 4 (2):122-124.

Singh, R., Y.P. Singh, N.P.S. Yaduvanshi and D.K. Sharma. 2009b. Effect of irrigation scheduling and integrated nutrient management on yield of rice - wheat system and properties of a reclaimed sodic soil. Journal of Indian Society of Soil Science, 57 (3): 280-286.

Singh, R.K.K., H.S. Athokpam, Z. Changte and N.G. Singh. 2005. Integrated management of Azolla, vermicompost and urea on yield and nutrient uptake by rice and soil fertility. Journal of Indian Society of Soil Science, 53 (1): 107-110.

Singh, R.P., P.K. Yadav, R.K. Singh, S.N. Singh, M.K. Bisen and J. Singh. 2006. Effect of chemical fertilizer, FYM and biofertilizer on performance of rice and soil properties. Crop Research, 32 (3): 283-285.

Singh, S.K., S.S. Verma and R.P. Singh. 2001. Effect of integrated nutrient supply on growth, yield nutrient uptake and economics and soil fertility in irrigated rice. Oryza, 38 (2): 56-60.

Subhendu Mandal and J. Adhikary. 2005. Effect of integrated nitrogen management on growth and yield of rice (Oryza sativa L.).Agricultural Science Digest, 25 (2): 136138.

Sunitha, B. P., H.C. Prakasha and K.T. Gurumurthy. 2010. Influence of organics, inorganics and their combinations on availability, content and uptake of secondary nutrients by rice crop (Oryza sativa L.) in Bhadra command, Mysore, Karnataka. Journal of Agricultural Sciences, 44 (3): 509-516.

Surekha, K. and K.V. Rao. 2009. Direct and residual effect of organic sources on rice productivity and soil quality of vertisols. Journal of Indian Society of Soil Science, 57 (1): 53-57.

Surekha, K., K.V. Rao and B.C. Viraktamath. 2008. Organic farming in rice. Kisan World Magazine, 13 (2): 13-16.

Sutaliya, R. and R.N. Singh. 2005. Effect of planting time, fertility level and Phosphate solubilizing bacteria on growth, yield and yield attributes of winter maize under rice maize cropping system. Indian Journal of Agronomy, 50 (3): 173-175. 
Swarnkar, A.K., V.M. Victor and A.S. Rajput. 2005. Evaluating Integrated Nutrient Management for the Biasi System of Rainfed Rice Cultivation. International Rice Research Newsletter, 30 (1): 34-35.

Talathi, M.S., S.S. Pinjari, N.J. Ranshur, T.S. Bhondave and J.S. Suryawanshi. 2009b. Response of hybrid rice (Oryza sativa L.). to green leaf manure, FYM and chemical fertilizers. International Journal of Agricultural Sciences,5 (2): 501-506.

Talathi, M.S., S.S. Pinjari, N.J. Ranshur, T.S. Bhondave and J.S. Suryawanshi. 2009a. Productivity and economics of rice groundnut cropping system under integrated nutrient management. International Journal of Agricultural Sciences, 5 (2): 472-476.

Urkurkar, J.S., A. Tiwari, S. Chitale and R.K. Bajpai. 2010. Influence of long term use of inorganic and organic manures on soil fertility and sustainable productivity of rice (Oryza sativa) and wheat (Triticum aestivum) in inceptisols. Indian Journal of Agricultural Sciences, 80(3): 208-212.

Ushakumari, K., M.S. Sailajakumari and P.C. Sheeba. 2006. Vermicompost: A potential organic nutrient source for organic farming. $18^{\text {th }}$ World Congress of Soil Science, Pennsylvania, USA. pp 162-178.

Vats, M.R., D.K. Sehgal and D.K. Mehta. 2001. Integrated effect of organic and inorganic manuring on yield sustainability in long-term fertilizer experiments. Indian Journal of Agricultural Research, 35 (1): 19-24.

Venkatakrishnan, D. and M. Ravichandran. 2012. Effect of integrated nutrient management on sugarcane yield and soil fertility on an UlticHaplustalfs. Journal of Indian Society of Soil Science, 60 (5): 74-78.

Vipin K., R.K. Prasad, S.N. Suman and S. Tiwari. 2011. Integrated nutrient management for better soil fertility and rice productivity. Oryza,48 (4): 335-338.

Viraktamath, B.C. 2006. Evaluation of System of Rice Intensification (SRI) under All India Coordinated Rice Improvement Project. In: National Symposium on System of Rice Intensification (SRI), Present Status and Future Prospects, $17-18^{\text {th }}$ November 11. pp. 205-213.

Yadav, B.K. and A. Christopher Lourduraj. 2006. Effect of organic manures and panchagavya spray on rice (Oryza sativa L.) quality. Crop Research, 31 (1): 6-10.

Yadav, O.M., R.V. Dahiphale and G.V. Goghawale. 2007. Effect of integrated nutrient management on productivity of rice (Oryza sativa L.) under upland eco-system. International Journal of Tropical Agriculture, 25 (2): 201-207.

Yadav, R.L. 2000. On-farm experiments on integrated nutrient management in rice-wheat cropping systems. Experimental Agriculture, 37 (1): 99 - 113.

\section{How to cite this article:}

Syed Abul Hassan Hussainy and Arivukodi, S. 2020. Performance of Rice under Integrated Nutrient Management: A Review. Int.J.Curr.Microbiol.App.Sci. 9(04): 1390-1404. doi: https://doi.org/10.20546/ijcmas.2020.904.165 